\title{
Epistemic Attitudes and Theistic Commitment
}

\section{Gellman J*}

Department of Philosophy, Ben-Gurion University of the Negev, Israel

*Corresponding author: Jerome Gellman, Department of Philosophy, Ben-Gurion University of the Negev, Israel, Tel: 972-54-5467-211; Email: gellman@bgu.ac.il

\section{Conceptual Paper}

Volume 1 Issue 1

Received Date: August 10, 2018

Published Date: September 04, 2018

DOI: $10.23880 /$ phij- 16000105

\begin{abstract}
I consider the view that theistic commitment must be a decisive and the opposing view that theistic commitment must be only tentative. I argue that the multiplicity of kinds of religious commitments complicates the issue for the first view, and so tentative commitment has its place. Then I offer a pragmatic justification for the validity of decisive commitment, against the view that would disallow it.
\end{abstract}

Keywords: Religious commitments; Decisive; Religious; Personal; Grouply

A person's commitment or ("adherence") to a cause, to a way of life, or to an idea can be "tentative" or "decisive." When a person has a tentative commitment, she keeps in mind the possibility that she might need to revise or even abandon her commitment, in light of what might newly develop. She has openness to inquiry and a readiness to change commitments if necessary. (Some have called this "interim assent."). Tentative commitment is opposed to decisive commitment. With a decisive commitment, a person has her firm commitment and does not engage in continued reflection on its adequacy. She does not revisit the possibility of having to forsake or revise the commitment as a result of further inquiry. She sticks to its decisively.

It is a common position that theistic ${ }^{1}$ commitment must be decisive. Consider these few examples. The Hebrew Bible, as repeated by Jesus, wants "all your heart and all your soul." A list of traditional Jewish beliefs begins each line with reference to "complete" (or "perfect") faith. Long ago, the Athanasian Creed declared of itself, "which except a man believe truly and firmly, he

${ }^{1}$ Some of the arguments that follow will apply best to theistic religions. So, my use of "religious" will pertain mostly to theistic religions and will appear for the sake of variety with "theistic." cannot be saved." The Theological Guidelines of the United Methodist Church begins with, "Faith is the basic orientation and commitment of our whole being-a matter of heart and soul" 2 . These all reflect a call for what is here being called "decisive" religious adherence.

Several philosophers of religion have concurred. Alasdair MacIntyre, a Catholic philosopher, wrote that in Christianity a person must have a "decisive adherence" to the religion:

[Provisional, tentative] adherence is completely uncharacteristic of theistic belief. A God who could be believed in this way would not be the God of Christian theism. For part of the content of Christian belief is that a decisive adherence must be given to God. So that to hold Christian belief as a hypothesis would to render it no longer Christian belief ${ }^{3}$.

A "decisive" adherence, according to MacIntyre, is incompatible with taking belief in God as a hypothesis

\footnotetext{
2 http://www.umc.org/what-we-believe/theological-guidelines, accessed August 28, 2018.

${ }^{3}$ Alasdair MacIntyre, "The Logical Status of Theistic Belief," in Stephen E. Toulmin, Ronald W. Hepburn, and Alasdair MacIntyre, Metaphysical Beliefs (London: SCM Press, 1957), p. 171.
} 
that might be overturned and therefore should be held only tentatively. This follows presumably from one having to surrender oneself to God and God's will. This reasoning goes beyond Christianity to other theistic religions as well.

Another Catholic philosopher, Gary Gutting, concurs that theistic belief must be what he calls a "decisive assent," rather than an "interim assent:"

Decisive assent... terminates the process of inquiry. It means that I view the present case for $p$ as allowing me to end the search for reasons for and against believing $\mathrm{p}^{\prime 4}$.

Gutting maintains that "a belief is religious not only in virtue of its content (e.g., the fact that it is about God [or the sacred]) but also in virtue of the way it functions in the life of one who holds it." Accordingly, Gutting holds that theistic belief must be "decisive" and not "interim" assent. ${ }^{5}$ Gutting argues that in theistic belief God must be one's "master passion" and that a theistic belief requires decisive action, including a willingness to give up earthly goods. Both are inconsistent with tentative belief.

Terence Penelhum took a similar position to this (at a period of his life before he returned to the Christianity of his youth ${ }^{6}$. Penelhum wrote in favor of what he calls "total commitment" in theistic religion. He writes that theistic belief is not tentative, and that:

The basic reason for this total commitment is, as theistic thinkers have always insisted, that faith is not in which someone considers himself to know certain things about God, but is also a personal acceptance and commitment to the God about whom these things are considered known? ${ }^{7}$.

Commitment to God cannot be tentative or less than total. This follows, presumably, from the nature of God and what God wants of us. Hence, a theistic commitment must be total.

These philosophers argue for a decisive commitment because of a demand of unconditional commitment to God. There is another, connected, reason for a devotee to

\footnotetext{
${ }^{4}$ Gary Gutting, Theistic Belief and Theistic Skepticism (Notre Dame: University of Notre Dame Press, 1982), p. 105.

${ }^{5}$ Gutting, p. 106.

${ }^{6}$ See his biographical account in Terence Penehulm, "A Belated Return," in Kelly James Clark, editor, Philosophers who Believe, The Spiritual Journeys of 11 Leading Thinkers (Downers Grove, Ill.: Inter Varsity Press, 1993), pp. 223-236.

7Terence Penelhum, Problems of Theistic Knowledge (New York: Herder and Herder, 1971), p. 133.
}

adopt a decisive commitment. Religions typically call for a follower to devote himself to rigorous, long-term selftransformation, or uncovering of one's deep, true self, one involving moving away from being oriented toward one's own self-needs to acquiring a character of self-denial for the sake of others. In Christianity the self-transformation includes becoming Christ-oriented, in Judaism it includes becoming like God through the Torah, and Islam stresses reaching a "purity of soul." Religions provide differing tools and mechanisms for advancing on this mission. A commitment to self-transformation or to uncovering one's true, beneficent self involves sustained systematic undertakings including at times demanding regimens to. One might well feel that God is aiding one's efforts and pray for God's grace, yet the task requires a long-range undertaking whose success calls for constant diligence and sacrifice. Such an undertaking, to have a good chance for success, cannot be tentative. It must be decisive. If one were to have such a commitment only tentatively one could be expected to give it less than one's all, less than the intensity and wholeness of purpose it requires to have a chance to succeed. If one were to switch one's religious orientation and with it the form of life involved one might lose the benefit of one's present hopes and successes. Keeping open to that eventuality can weaken and be a distraction from the comprehensive task at hand.

Robert McKim disagrees with the view that theistic adherence should be decisive. McKim argues that considering the diversity of the world's religions, a person is justified in holding only a tentative religious commitment. McKim argues for this conclusion from a principle he calls the "T-principle"8. This principle states that:

Disagreement on a matter between people with relevant integrity and competence, provides a reason for a person to adopt only a tentative commitment on that matter.

This principle, argues McKim, applies to the diversity of world religions. An adherent of a given religion will know of devotees of other religions who have obvious integrity and competence. Those others explicitly reject at least some of the central tenets of his religion. Therefore, by Principle T, a theistic devotee is justified in having only a tentative commitment to his religion. That is, he must be open to continuous inquiry and not be decisively committed to his religion.

\footnotetext{
${ }^{8}$ Robert McKim, Theistic Ambiguity and Theistic Diversity (Oxford: Oxford University Press, 2001), p. 141. I am indebted to Mckim to leading me to the views of MacIntyre, Gutting, and Penelhum.
} 
McKim means to argue that whether theistic commitment is supposed to be held decisively, it is not justified to hold it in such a manner.

These contrasting views of the epistemic attitudes involved in theistic commitment overlook important relevant distinctions concerning their subject matter. When these distinctions are factored in we will find that there is no one across-the-board answer as to the nature of theistic commitment. Accordingly, in what follows I distinguish twice between categories of theistic commitment and relate them to the tentative-decisive contrast. These distinctions are between: (1) personal and grouply commitments, and (2) commitments reflecting belief and those reflecting acceptance. Following that, I will offer a proposal for finding a way between the tentative and the decisive positions by introducing what I will call: tentatively decisive commitment.

\section{Personal vs. Grouply}

When a person has a commitment of a personal nature, she tends to feel and support that commitment and act on it in contexts in which she is not, or at least not primarily, thinking of herself as identified with a group that endorses that commitment. When a person has a commitment of a grouply nature, she tends to feel and endorse the commitment and act on it primarily when she is identifying herself as a member of a relevant group. It is more like "We Calvinists believe...." and less like "I believe...." There are gradations in the distinction and cases where we will not be able to determine if a commitment is personal or grouply. But there are also clear cases where the distinction applies.

To illustrate what I am calling "grouply commitment," consider the following episode from an ethnographic study of the Tully River Tribe of Australia by the ethnographer, Walter Roth, in $1900^{9}$. Roth reported that Tully River natives told him that a woman becomes pregnant by touching a certain kind of frog, by having certain dreams, or by eating a certain kind of beans. Roth concluded that the Tully River folk had no knowledge of the true biological cause of conception by heterosexual relations.

This gave rise to the "Tully River Controversy" in anthropology. According to Edmund Leach it was wildly implausible to think that these natives had not hit upon the biological cause of conception. Thus, Leach insists that

${ }^{9}$ Walter E. Roth, On the Natives of the (Lower) Tully River (Cooktown, Australia: Queensland Home Secretary's Department, Office of the Northern Protector of Aboriginals, 1900). the tribe-members must have known that heterosexual relations caused pregnancy. Leach maintains that "When an ethnographer reports that 'members of the $\mathrm{X}$ tribe believe that...' he is giving a description of ... something which is true of the culture as a whole" 10 . This means that the members of the tribe made their magical claims about causes of pregnancy qua members of their tribal culture, while holding different personal beliefs. Leach claimed that only in public pronouncements when speaking for their tribe and its culture did the natives have recourse to magical explanations of pregnancy. In private, they spoke of conception and pregnancy in quite ordinary terms.

Suppose Leach is correct about the Tully River split between grouply and personally held positions on magical conception. Leach is proposing what I am calling a "grouply" commitment to magical pregnancy. In their process of acculturation, tribal individuals acquired a commitment to think of magical conception when thinking grouply. Otherwise, when not acting or identifying as tribal members, they held quite ordinary views on how a woman enters pregnancy. On the personal level they were not committed to speaking of magical means of entering pregnancy.

A group of theistic devotees is not simply a collection of people whose personal theistic commitments happen to coincide. The strong group-character of religion, which Emile Durkheim recognized ${ }^{11}$ and Sigmund Freud sometimes ignored, ${ }^{12}$ suggests the importance of grouply held commitments among the members of a religion. A person typically acquires and sustains theistic commitments as a member of a theistic group and may end up holding a commitment only as a member of the group. So, for example, a given Catholic might have only a grouply commitment to upholding and advancing the doctrine of double procession, that the Holy Spirit proceeds from the Father and the Son together. As a Catholic, he is committed to it. ("We Catholics believe in double procession.") Yet, personally, when momentarily standing outside "the circle of faith," he may find himself without any real opinion on the matter. This should be expected especially for dogmas like that of double procession, which do not figure much in the life of a devotee. Another example might be a Jewish belief in the ultimate coming of the Messiah. When asked in a theistic

\footnotetext{
${ }^{10}$ Edmund Leach, Genesis as Myth and Other Essays (London, J. Cape, 1969), p. 88.

${ }^{11}$ This is basically the theme of Emile Durkheim, The Elementary Forms of the Theistic Life Translated by J. W. Swain (New York: Free Press, 1965).

${ }^{12}$ As evidenced by his reduction of theistic adherence to individual psychology in Sigmund Freud, The Future of an Illusion, Translated and edited by James Strachey (New York: W.W. Norton, 1989).
} 


\section{Philosophy International Journal}

context about this dogma, a traditional Jew might readily affirm its truth ("We Jews believe that the Messiah is yet to come."), but when home and trying to fall asleep at night she might want to doubt it or have no real opinion on the matter. Quite likely, instances of theistic commitment are a mix of grouply-held and personally held commitments, with dynamic interchange between the two over a person's history.

Given this distinction, the issue of decisive vs. tentative becomes more complex than otherwise. Now, new possibilities open. One is that grouply theistic adherence at times could be aligned with decisive commitment while at the same time on a personal level be no more than tentative. This can happen, for example, from strong identity with the group's values, aims, and ethos. Or it could happen from an individual need for strong group identity beyond one's own self-identity. Despite this, when alone and contemplating the entire context one could have hesitations or doubts that she does not allow to seep into her grouply commitment. The decisiveness could be exhibited when thinking of oneself as a Baptist, say, and then always refraining from raising or even thinking any issue that might weaken or detract from the strength of the Baptist group decisiveness. And it could be expressed as well in enthusiastic and sustained activity in the group's affairs. At the same time, behind the scenes, as an individual, one might be asking questions and vaguely entertaining possibilities other than the Baptist Church. Given what is plausibly a not uncommon epistemic attitude in religious adherence, we would do well to recognize that a grouply commitment may be decisive, but not the whole story.

Grouply decisive commitments might not fit what MacIntyre and others quite meant by "decisive" or "total" commitment. Yet, recognizing grouply commitment blurs the stark distinction between tentative and decisive commitment and put is on guard for gradations of a mix between the two.

\section{Belief and Acceptance}

My second distinction is between belief-based and acceptance-based commitment. I begin with the difference between belief and acceptance, in the meantime confining my presentation to personal, rather than grouply, contexts. When a person believes something, as when a philosopher believes that there are moral facts, she will have two dispositions. One is a disposition to have a distinctly belief feeling that there are moral facts. A belief feeling is an internal awareness of a sense of conviction. The other disposition is to behave in appropriate ways in relevant circumstances. This would include being inclined to saying that there are moral facts, using that there are moral facts as a premise in her practical reasoning, and acting in light of there being moral facts, when appropriate. Thus, belief is a dispositional complex of both feeling and behavior. And both are something that happens to the person. One finds oneself with one's beliefs, not choosing or deciding to have them.

I will say that a person accepts something, as when a philosopher might accept that the Ontological Argument is sound, when he has the appropriate behavioral disposition, as before, but does not have a disposition to experience that inner belief-feeling that the argument is sound. For example, he has considered the arguments of philosophers for and against the Ontological Argument and concludes that the considerations in its favor are far stronger than those against. However, the arguments on behalf of the argument are not quite enough to create in him the belief that the argument is sound. He lacks a disposition to have that special inner belief-feeling. So, he decides to accept as his philosophical position that the Ontological Argument is sound. He adopts it, thinks in terms of its being sound, will advance this view, and defend it against critics and argue against deniers. He would be expected to explore further the implications of the existence of a perfect being. He accepts that the Ontological Argument is sound. He accepts, but does not believe, not because he doubts it or disbelieves it, but because he only accepts it. Acceptance, as opposed to belief, is ordinarily voluntary, assuming a position deliberately, or nearly deliberately ${ }^{13}$.

Another example. You weigh the merits of a candidate for Prime Minister and find that much points to one person being the best candidate. However, you do not quite believe it. But you do have enough to go on to be prepared to accept that she is the best candidate. So, you vote for her, hope she wins, and tell others to vote for her, as well. You have accepted something that you do not quite believe.

Everything else being equal, a commitment to something because of, or in step with, what one accepts can be expected to be less decisive than a commitment on account of what one believes. One simply finds oneself with a belief-feeling, whose power could propel one to a decisive commitment. The commitment will tend toward the decisive. Not necessarily so for commitment because of what one only accepts. Acceptance involves a voluntary embracing of a proposition, typically because of weighing

\footnotetext{
${ }^{13}$ From the large literature on the distinction between belief and acceptance, my presentation here follows closely William Alston, "Belief, Acceptance and Theistic Faith," in Jeff Jordan and Daniel Howard-Snyder, editors, Faith, Freedom, and Rationality (Lanham and London: Rowman and Littlefield, 1996). See also XXXXXXXXXXX.
} 


\section{Philosophy International Journal}

up pros and cons and coming out in favor. When that is the case, one might be expected to keep an eye on possible changes in the balance of evidence or reasons for and against what has been accepted. In addition, one can be expected to stake more of one's self and what is of importance on a belief than on an acceptance. Also, generally speaking, a belief is not as easily dislodged, as is what one (merely) accepts. So though admittedly not always, we should expect a more intense commitment to belief than to acceptance.

The distinction between belief and acceptance cuts across the difference between personal and grouply attitudes. I propose, and this will be controversial, that a person could have an exclusively grouply belief. A grouply belief would obtain when one has the tendency to have the appropriate, real, belief-feeling about a proposition that the group maintains when thinking of oneself as a member of the group and yet fail to have that tendency in personal contexts. There is no reason to suppose that such tendencies must be all or nothing for all and every context. They could be triggered selectively by the category of a present context.

Theistic commitments can be either belief-based or acceptance-based. A theistic adherent will have an acceptance-based commitment when he has made a conscious decision of acceptance, but when he does not have a belief-feeling at the basis. We should expect that for any given theistic person, commitments to some of the elements of the religion will be belief-based, while others will be merely acceptance-based. Also, we should expect acceptance-based theistic commitment to be less intense than belief-based commitment.

Hence, the demand that theistic adherence be decisive goes better with wanting theistic adherence to be based on appropriate theistic beliefs, rather than on acceptances. Since it is ordinarily impossible to decide to have a belief, including a theistic one, the demand that theistic commitment be decisive, which goes best with a beliefbasis, should amount to no more than having a belief-base as an ideal, while being able to recognize acceptance as at least a tolerable interim epistemic attitude.

While one might set up decisive commitment as a goal it should be clear that religious belief is manifest by a variety of epistemic attitudes. These include ones that fall short of being decisive, and the formation of which organized religions enhance on the ground. The social character of a religion and what is often a demand for compliance beyond the belief capacity of a person makes room for and can even encourage, respectively, grouply commitment and acceptance, rather than personal belief.
These are natural effects of organized religions that make demands of adherence.

\section{Religions and Shows of Commitment}

On the other hand, religions surely want their devotees to have not only grouply commitments but personal ones as well. And we have seen the demand that followers have decisive rather than tentative commitments. So, religions will see value in promoting the impression that their devotees are committed personally and not just grouply to their religion. And, religions will see value in promoting the impression that commitment reflects belief rather than acceptance. These impressions will enhance greater expectations for decisive adherence.

Religions have mechanisms for creating a pragmatic implication that adherents are committed personally, not just grouply, and as the result of having a full-blown belief. This is well illustrated when establishing, and sometimes also performing ritual recitations of, creedal formulations formulated as individual belief. These fulfill the desire that "you all speak the same thing, and there be no divisions among you; but you be perfectly joined together in the same mind and in the same judgment. (1 Corinthians 1.10) The "same mind" can be construed as referring to personal commitment, and "same judgment" as referring to shared belief. So, for example, the Apostles Creed begins and continues with "I believe." (Note that the Nicene Creed, in contrast, repeats that "We believe.") The Protestant Westminster Confession refers throughout to individual belief. While Judaism has no official creed, the closest to one is the Ani Maamin ("I believe") statement of thirteen principles of faith, based on Maimonides. It is thirteen statements of personal belief, starting with, "I believe with complete faith that the Creator, blessed be His name, is the Creator and Guide of all the created beings, and that $\mathrm{He}$ alone has made, does make, and will make all things".

Religions are strengthened when their adherents have personal beliefs in the religion, for this enhances decisive commitment. When devotees will likely have other epistemic attitudes as the ground of their theistic commitment it can be useful to create an impression otherwise.

\section{Back to Religious Diversity}

We have seen Robert McKim arguing that considering the diversity of religions the devotee of a religion should commit to the religion only in a tentative manner, not decisively. Cognizant of other knowledgeable, intelligent 
people who disagree with his religious commitment the devotee should be aware of the possibility of his having to change his mind about his religious adherence in accordance with the views of those who disagree with his religion.

Once upon a time, religious devotees overwhelmingly knew little of religions other than their own. And what they did know of them, often those religions and/or their followers were perceived as evil and threatening. Mckim is addressing us religious devotees for whom matters today are very different. We know about religions other than our own and know how to find out much more. Some of us even have studied other religions and their beliefs. A devotee of one religion has contact and friendships with members of other religions and is familiar with them in mass communication and otherwise. We know at least some of these others to be decent, intelligent, thoughtful people and learn of their religious commitments and ways of life. And we know these others to be as decisively committed to their religions as we are. The situation is one of the cultural presence of religions in competition with our own in terms of truth-claims and mandated behavior.

McKim wants us living in such a milieu to adopt his TPrinciple that "Disagreement on a matter between people with relevant integrity and competence, provides a reason for a person to adopt only a tentative commitment on that matter." Hence, we religious devotees he addresses should take care to refrain from having a decisive religious commitment.

A reason not to agree with McKim's T-Principle rises when we realize that this principle applies far beyond the issue of religious diversity. Similar cultural diversities exist for a great many of our large-scale commitments. Our cultural contexts confront us with important alternatives in values, life goals, political policies, beliefs and acceptances, and all sorts of professional and private choices. These other views and pursuits are held and followed by people we realize to be as intelligent, sincere, and informed as are we. Given this situation, unless we have something like a "proof" of our position, which we seldom have, Mckim would have us adopt the great array of our commitments only tentatively, barring us from decisive commitments.

In fact, McKim's T-Principle, when telling us how to relate to the myriad commitments that are the constituents of life, is telling us how to live our lives. When seeing it in this light, we have good reason to reject such a ban on decisive commitments. That is because so much of life gets its meaning precisely from the decisive commitments that carry us forward in roads taken, with other roads not taken now left behind. Large-scale tentative decisions do not have what it takes to grant a person a sense of a life well-lived, a life well-confronted. Decisive commitment is needed to look on one's life as one's own and as being engaged to its fullest. For that we need to commit beyond our knowledge and beyond disagreement with others. Imagine what life would look like were we to have to remain always open to switch to what peers are committed. Imagine the lack of robust engagement in such a life. Life is a gamble. You put your money down and go with it. The meaning in doing so is not only in hoping to be a winner, but in having put down the bet and living it out the best we can, if we can. Of course, we can change from one decisive commitment to another, but that can be because of what happens to us within our commitments and need not be because of an obligation to be on the lookout for a possible shift. Now, one of the most meaningful of all our commitments is our religious one. If you are a believer, your religion has high ranking in your life's meaning. Decisive commitment to God and to self-transformation within a religious package can be the most decisive commitment one might have. And with it, life receives profound meaning.

Now, I am not arguing for pursuing meaning above all else, certainly not above established truth or above the most obvious of moral demands. Yet, I am proposing a practical, pragmatic, if you like "existential," justification for validating decisive religious commitments in the face of religious diversity. The time for decisive life commitments comes early and cannot wait until it is too late. Pragmatic justifications figure elsewhere in epistemology, as for example, in William Alston's pragmatic defense of following our doxastic practices although any justification for doing so will be circular ${ }^{14}$ and they should have an honored place in our epistemic desirata.

To sum it up, I have proposed distinguishing different forms of religious commitment: personal from grouply, and belief-based from acceptance-based. Given these distinctions I have argued, against the view of some, for recognizing the possibility and acceptability of types of tentative religious commitments. In addition, I have contended, on the other hand, that we should not accept McKim's argument for the conclusion that religious commitment must not be decisive. I have proposed a pragmatic justification for just such commitments.

\footnotetext{
${ }^{14}$ See William P. Alston, The Reliability of Sense Perception (Ithaca and London: Cornell University Press, 1993) and Perceiving God ((Ithaca and London: Cornell University Press, 1991).
} 